\title{
Binding of neomycin and analogues by fatty acids in vitro
}

\author{
R. W. LACEY \\ From the Department of Clinical Pathology, Bristol Royal Infirmary, Bristol
}

SYNOPSIS Neomycin forms insoluble complexes with long-chain fatty acids in vitro. This reducesi the diffusion of neomycin but does not directly neutralize its antibiotic activity. Possible effectser in vivo are discussed.

The activity of antibiotics in vivo may be reduced by their interaction with constituents of blood or tissues, for example, the protein binding of penicillin and the binding of neomycin to mucus (Saggers and Lawson, 1966). During a study of the action of antibiotics on cutaneous bacteria in vitro, neomycin was found to precipitate long-chain fatty acids of the type present in skin. As neomycin and its analogues are used mainly topically and orally, the reaction with fatty acids could occur in both these sites. The purpose of this paper is to describe an investigation of reactions in vitro between fatty acids and several aminoglucoside antibiotics.

\section{METHODS AND RESULTS}

As long-chain fatty acids are almost insoluble in water, the more soluble sodium salts were used. These were added in aqueous solution to a solution of neomycin sulphate (Boots Pure Drug Co.) in phosphate buffer. The final concentration of acid was $0.3 \mathrm{~g} / 100 \mathrm{ml}$, of neomycin base $0.1 \mathrm{~g} / 100 \mathrm{ml}$, and buffer $\mathrm{M} / 10, p \mathrm{H} \cdot 4$. After incubation at $37^{\circ} \mathrm{C}$ for 60 minutes, the mixtures were vigorously shaken and $0.10 \mathrm{ml}$ aliquots were assayed for neomycin activity. A cup diffusion method, based on that of Grove and Randall (1955), was used, with the Oxford staphylococcus as the test organism. A standard curve was obtained by assaying neomycin sulphate in the buffer without fatty acids.

On adding neomycin to solutions containing fatty acids with 12 or more carbon atoms, there was an immediate precipitate, followed within 60 minutes by coarse flocculation. Short-chain acids did not precipitate. Assay of the antibiotic in mixtures showed marked loss of neomycin activity in those in which a precipitate had formed, but not in the others (Table I).

Received for publication 28 February 1968.
TABLE I

EFFECT OF INCREASING CHAIN LENGTH ON FATTY ACIBO INACTIVATION OF NEOMYCIN SULPHATE, IN M/10 PHOSPHATED BUFFER, $p$ H $7 \cdot 4$

Fatty Acid $(0.3 \mathrm{~g} / 100 \mathrm{ml})$ and No. of Carbon Atoms Precipitation Percentage Activity
with Neomycin of Neomycin Sulphate Sulphate $\quad(0.1 \mathrm{~g} / 100 \mathrm{ml})$ in $(0.1 \mathrm{~g} / 100 \mathrm{ml})$ in
Presence of Various Fatty Acids

Control (no fatty acid added)
Acetate (2)
Propionate (3)
Butyrate (4)
Hexoate (8)
Octoate (10)
Laurate (12)
Myristate (14)
Palmitate (16)
Stearate (18)
Oleate (18)
Linoleate (18)
Linolenate (18)

To determine whether the loss of neomycin $\frac{}{3}$ activity was due to impaired diffusion of the anti-i biotic or to actual inactivation of it, sets of nutrient 3 agar plates were prepared containing a range of neomycin concentrations $(0.1$ to $6.4 \mu \mathrm{g} / \mathrm{ml})$ and $a^{2}$ constant concentration of one or other of three fatty $\frac{D}{O}$ acids. As a control, a fourth set of plates was prepared without fatty acid. Segments of the plates $N$ were inoculated with six strains of Staphylococcus aureus and the minimum inhibitory concentration (MIC) of neomycin was read after incubation for ${ }^{\omega}$ 20 hours at $37^{\circ} \mathrm{C}$. Similar experiments were performed with other aminoglucosides. The results are summarized in Table II. The presence of fatty acid $\Phi$ in the medium had no significant effect on the $\mathrm{MIC}_{-}^{-}$ of the antibiotics. The loss of activity in the previous diffusion experiments was therefore probably due $\frac{}{1}$ to binding without inactivation of the drug.

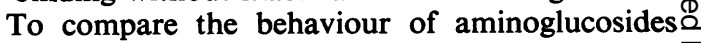


TABLE II

RANGE OF MINIMAL INHIBITORY CONCENTRATIONS OF AMINOGLUCOSIDE ANTIBIOTICS FOR SIX SENSITIVE STRAINS OF STAPHYLOCOCCUS AUREUS ${ }^{1}$

\begin{tabular}{|c|c|c|c|c|}
\hline $\begin{array}{l}\text { Antibiotic } \\
\text { (as Sulphate) }\end{array}$ & $\begin{array}{l}\text { Control } \\
\text { (no fatty } \\
\text { acid added) }\end{array}$ & $\begin{array}{l}\text { Palmitate } \\
+0.2 \% \\
(w / v)\end{array}$ & $\begin{array}{l}\text { Oleate } \\
+0 \cdot 2 \% \\
(w / v)\end{array}$ & $\begin{array}{l}\text { Stearate } \\
+0.2 \% \\
(w / v)\end{array}$ \\
\hline $\begin{array}{l}\text { Neomycin } \\
\text { Kanamycin } \\
\text { Gentamicin } \\
\text { Framycetin } \\
\text { Paromomycin }\end{array}$ & $\begin{array}{l}0 \cdot 8-1 \cdot 6 \\
1 \cdot 6-6 \cdot 4 \\
0 \cdot 1-0 \cdot 4 \\
0 \cdot 4-0 \cdot 8 \\
0 \cdot 4-0 \cdot 8\end{array}$ & $\begin{array}{l}0 \cdot 4-1 \cdot 6 \\
1 \cdot 6-6 \cdot 4 \\
0 \cdot 1-0 \cdot 4 \\
0 \cdot 4-0 \cdot 8 \\
0 \cdot 8-1 \cdot 6\end{array}$ & $\begin{array}{l}0 \cdot 4-1 \cdot 6 \\
3 \cdot 2-6 \cdot 4 \\
0 \cdot 1-0 \cdot 4 \\
0 \cdot 4-0 \cdot 8 \\
0 \cdot 4-0 \cdot 8\end{array}$ & $\begin{array}{l}0 \cdot 4-1 \cdot 6 \\
1 \cdot 6-3 \cdot 2 \\
0 \cdot 1-0 \cdot 8 \\
0 \cdot 4-1 \cdot 6 \\
0 \cdot 2-0 \cdot 8\end{array}$ \\
\hline
\end{tabular}

with some other antibiotics in the presence of fatty acids, nutrient agar plates were prepared containing fatty acids $(0.5 \mathrm{~g} / 100 \mathrm{ml})$, adjusted to $p \mathrm{H} 7.4$ and seeded with Staph. aureus. Antibiotic discs (Mast) were placed on the plates, and after incubation for 20 hours at $37^{\circ} \mathrm{C}$, zones of inhibition were measured (Table III). Experiments were performed with 10 strains of Staph. aureus, each of which was sensitive

\section{TABLE III}

EFFECT OF INCORPORATION OF FATTY ACIDS IN PLAIN AGAR ON ANTIBIOTIC INHIBITORY ZONES AT $p \mathrm{H} 7 \cdot 4^{1}$

Antibiotic Disc

\begin{tabular}{llll} 
Radius $(\mathrm{mm})$ of Inhibition around Antibiotic Discs \\
\hline Plain & Oleate & Palmitate & Stearate \\
Agar & $+0.5 \%$ & $+0.5 \%$ & $+0.5 \%$ \\
& $(w / v)$ & $(w / v)$ & $(w / v)$ \\
\hline
\end{tabular}

\begin{tabular}{lrrrr}
\hline $\begin{array}{l}\text { Penicillin G } \\
1.5 \mathrm{U}\end{array}$ & 10.0 & 11.5 & 12.0 & 12.0 \\
$\begin{array}{l}\text { Tetracycline } \\
\quad 50 \mu \mathrm{g}\end{array}$ & 8.0 & 9.5 & 8.5 & 9.0 \\
$\begin{array}{l}\text { Streptomycin } \\
25 \mu \mathrm{g}\end{array}$ & 8.0 & 8.0 & 7.5 & 7.5 \\
$\begin{array}{l}\text { Neomycin } \\
\quad 10 \mu \mathrm{g}\end{array}$ & 7.5 & 2.0 & 1.5 & 1.5 \\
$\begin{array}{l}\text { Kanamycin } \\
\quad 30 \mu \mathrm{g}\end{array}$ & 9.0 & 6.0 & 5.0 & 5.0 \\
$\begin{array}{l}\text { Gentamicin } \\
\quad 10 \mu \mathrm{g}\end{array}$ & 8.5 & 2.5 & 2.5 & 3.0 \\
$\begin{array}{l}\text { Framycetin } \\
\quad 50 \mu \mathrm{g}\end{array}$ & 10.0 & 3.5 & 3.0 & 3.5 \\
$\begin{array}{l}\text { Paromomycin } \\
\quad 10 \mu \mathrm{g}\end{array}$ & 8.0 & 3.0 & 3.0 & 2.5 \\
& & & &
\end{tabular}

$10 \mu \mathrm{g}$

${ }^{1}$ Each figure is mean for 10 sensitive strains of Staph. aureus.

to all the antibiotics. Plates without fatty acids were included as controls. The growth of bacteria was completely inhibited by several acids-hexoate, myristate, laurate, linoleate, and linolenate. Acetate, propionate, butyrate, and octoate had little effect on growth or zone size. Palmitate, stearate, and oleate markedly reduced the size of zones around the aminoglucoside discs. By contrast the zones of inhibition around penicillin and tetracycline were slightly larger than in the control plates, probably because the growth of the organism was slowed by the fatty acid (Cooper and Gillespie, 1952). In similar experiments, it was found that fatty acids in a concentration as low as $0 \cdot 1 \mathrm{~g} / 100 \mathrm{ml}$ reduced the size of the zone around aminoglucoside discs. In experiments in which the $p \mathrm{H}$ of the medium was adjusted to $6 \cdot 0,7 \cdot 0$, and 8.0 by means of hydrochloric acid and sodium hydroxide, the results were similar, although the size of zones in the control

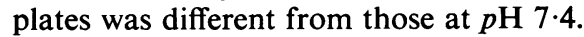

\section{DISCUSSION}

The above experiments indicate that the loss of activity of these antibiotics in the presence of fatty acids is due to the reduced diffusion of the complex. The union of fatty acids and neomycin in vivo could alter the activity of either fatty acids or neomycin; the former may be relevant to neomycin-induced steatorrhoea, and the latter to topical therapy with these drugs.

It is well established that oral neomycin causes steatorrhoea (Jacobson, Chodos, and Faloon, 1960; Hvidt and Kjeldsen, 1963; Rothfeld and Osborne, 1963; Asatoor, Chamberlain, Emmerson, Johnson, Levi and Milne, 1967), which is manifested by increased faecal fat, nitrogen, sodium, and calcium, with reduced carotene and xylose absorption. It has been suggested that bile salts, in particular sodium glycocholate, are precipitated by neomycin (Faloon, Paes, Woolfolk, Nankin, Wallace, and Haro, 1966) but these authors found that oral supplements of bile salts did not correct the steatorrhoea. Moreover, kanamycin caused little precipitation of bile salts at the $p \mathrm{H}$ of the small bowel contents, yet certainly caused substantial steatorrhoea. The precipitation of bile salts by the antibiotics does not therefore fully explain the steatorrhoea. The ability of the antibiotics to precipitate stearic, palmitic, and some long-chain unsaturated fatty acids, the main components of dietary fat, may also be a causative factor. Faloon et al (1966) showed that when neomycin was administered through a tube directly to the ileum, there was less steatorrhoea than when the drug was given by mouth. However, this result might also be explained by the fact that most of the dietary fatty acids are absorbed before they reach the ileum and so would not be available to unite with neomycin delivered there through a tube. The oral administration of $4 \mathrm{~g}$ of neomycin daily, on the basis of the in vitro assay, could bind about 12 to $15 \mathrm{~g}$ of longchain fatty acids. In six normal subjects, Asatoor et al (1967) found that this dose of neomycin increased the faecal fat by about $10 \mathrm{~g}$ daily, a figure certainly of the same order as the prediction in vitro.

The application of aminoglucoside antibiotics to the skin might result in their union with free fatty acids which make up about $40 \%$ of skin surface lipid (Ricketts, Squire, and Topley, 1951). It is 
possible that this binding could prolong exposure of the skin to these antibiotics and therefore increase the risk of allergy to them. Clinical evidence of this is seen after topical neomycin therapy. Kirton and Munro-Ashman (1965) claimed that neomycin allergy was due to the prolonged retention of the drug in the skin. The combination between skin neomycin and skin fats might also increase the tendency of neomycin-resistant staphylococci to proliferate. Such resistant strains were first seen in 1960 (Quie, Collin, and Cardle, 1960; Finegold and Gaylor, 1960) and have since become world wide (Lancet, 1965; Jevons, John, and Parker, 1966). Topical use of the antibiotics has often been quickly followed by the proliferation and spread of neomycin-resistant strains (Lowbury, Babb, Brown, and Collins, 1964; Rountree and Beard, 1965; Alder and Gillespie, 1967). The persistence of neomycin in the skin after treatment might well be a factor in encouraging the appearance of these strains.

I should like to thank Professor W. A. Gillespie, Dr
V. G. Alder, and Dr G. K. McGowan for their help criticisms. The work was supported by a grant from the Governors of the United Bristol Hospitals.

\section{REFERENCES}

Alder, V. G., and Gillespie, W. A. (1967). Lancet, 2, 1062.

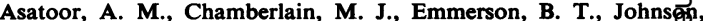
J. R., Levi, A. J., and Milne, M. D. (1967). Clin. Sci., 33, 19 . Cooper, K. E., and Gillespie, W. A. (1952). J. gen. Microbiol., 7, 10 Faloon, W. W., Paes, I. C., Woolfolk, D., Nankin, H., Wallace, K., and Haro, E. N. (1966). Ann. N.Y. Acad. Sci., 132, 879.

Finegold, S. M., and Gaylor, D. W. (1960). New Engl. J. Med, 263,1110 .

Grove, D. C., and Randall, W. A. (1955). Assay Methods of AR̆o biotics, p. 91. Medical Encyclopedia Inc., New York.

Hvidt, S., and Kjeldsen, K. (1963). Acta med. scand., 173, 699. Jacobson, E. D., Chodos, R. B., and Faloon, W. W. (1960). Amer? Med., 28, 524.

Jevons, M. P., John, M., and Parker, M. T. (1966). J. clin. Pagh, $19,305$.

Kirton, V., and Munro-Ashman, D. (1965). Lancet, 1, 138.

Lancet (1965). 2, 421.

Lowbury, E. J. L., Babb, J. R., Brown, V. I., and Collins, B. J. (1964) J. Hyg. (Lond.), 62, 221.

Quie, P. G., Collin, M., and Cardle, J. B. (1960). Lancet, 2, 124.

Ricketts, C. R., Squire, J. R., and Topley, E. (1951). Clin. Sci., 10,89. Rothfeld, B., and Osborne, D. (1963). Amer. J. dig. Dis., 8, 763. (D)

Rountree, P. M., and Beard, M. A. (1965). Med. J. Aust., 1, 498.

Saggers, B. A., and Lawson, D. (1966). J. clin. Path., 19, 313. 